\title{
GIS-based model of groundwater occurrence using geological and hydrogeological data in Precambrian Oban Massif southeastern Nigeria
}

\author{
Gregory Udie Sikakwe ${ }^{1}$
}

Received: 15 December 2017 / Accepted: 4 April 2018 / Published online: 14 May 2018

(C) The Author(s) 2018

\begin{abstract}
This researchmodeled geological and hydrogeological controls on groundwater occurrence in Oban Massif and environs southeastern Nigeria. Topographical, hydrogeological, and structural maps, including lithology samples from drilled bores, well completion, and pumping test data in the study area were procured. Collection of coordinates of rock sample locations and structural data on strike and dip of rock exposures was collected. Geological and structural information collected was overlaid on the topographical, hydrogeological and structural map and digitized to produce the geological map of the study area. Thematic map on geological groundwater prospect map of the study was prepared using multicriteria evaluation. Relative weights were assigned to various rock types based on their relative contribution to groundwater occurrence and the map was reclassified using geographic information system (ArcGIS10.1) analysis. Depth ranges of the various lithologic units from drilled boreholes were used to construct lithologic correlation section of the boreholes across the study area using RockWorks 16 Program software. Hydrogeological parameters such as storativity, specific capacity, transmissivity, drawdown, pumping rate, static water level, total depth, and well yield were computed from well completion reports and aquifer test. Results shows that the geologic groundwater prospect map was categorized into very good $\left(28.73 \mathrm{~m}^{2}\right)$, good $\left(9.66 \mathrm{~m}^{2}\right)$, moderate $\left(35.08 \mathrm{~m}^{2}\right)$, fair $\left(49.38 \mathrm{~m}^{2}\right)$, and poor $\left(77.63 \mathrm{~m}^{2}\right)$ zones. Aquifer parameters showed ranges such as (specific capacity $\left(1.81-31.16 \mathrm{~m}^{2} /\right.$ day $\left./ \mathrm{m}\right)$, transmissivity $\left(0.0033-12 \mathrm{~m}^{2} /\right.$ day $)$, storativity $\left(9.4 \times 10^{-3}-2.3\right)$, drawdown $(2.2-17.65 \mathrm{~m})$, pumping rate $(0.75-3.57 \mathrm{l} / \mathrm{s})$, static water level $(0-20.5 \mathrm{~m})$, and total depth $(3.3-61 \mathrm{~m})$. Borehole depths obtained in the basement are shallower than those in the sedimentary area. Aquifer test parameters obtained from boreholes across the study indicate better correspondence with zones identified as good water prospect in the study. It was evident that well yield is not a very reliable aquifer performance indicator, because it depends largely on the efficiency of the pump installed. Therefore, other aquifer parameters must be employed in aquifer performance assessment. The geologic formation is paramount in determining aquifer performance. The result of this groundwater occurrence is useful as a guide for groundwater developers, which engineers in water resource management and land-use planners to select suitable areas to implement development schemes and also government agencies.
\end{abstract}

Keywords Oban Massif $\cdot$ Multicriteria evaluation $\cdot$ Lithologic correlation $\cdot$ Hydrogeological parameters $\cdot$ Groundwater occurrence

Gregory Udie Sikakwe

udie.gregory@funai.edu.ng

1 Department of Physics/Geology/Applied Geophysics, Federal University, Ndufu-Alike, Ikwo, P.M.B 1010, Abakaliki, Nigeria

\section{Introduction}

Groundwater is noted to be one of the most valuable natural resources used as a major source of water in villages and communities for agricultural, industrial, and domestic purposes (Rahmati et al. 2016). Groundwater is found in the zone of saturation which occupies the cracks in rock masses or pore spaces among mineral grains (Berhanu et al. 2014). As the demand for groundwater continues to soar worldwide, the need for delineation of groundwater potential 
zones becomes a vital tool for conducting a result-oriented groundwater determination, protection, and management schemes (Naghibi and Pourghasemi 2015). The advantages of groundwater are based on its attributes such as consistent temperature, widespread availability, limited vulnerability, excellent natural quality, low cost of development, and drought reliability (Jha et al. 2007; Razandi et al. 2015). Other qualities of groundwater over surface water are: it is less affected by disasters and can be exploited when needed.

About two-third of Nigerian landmass is made up of basement rocks and Oban Massif is in the basement area. Groundwater exploitation in hard rocks is difficult, because, in hard rocks, water is restricted to secondary porosity and thus to the fractures and the weathered zones. Such areas experience water shortage, because drilling on hard rocks has low success ratio. Knowledge of the geology of such areas is important for the success of rural water development (Bala 2009). Groundwater exploration entails delineation and mapping of the different lithological, structural, and geomorphic units (Solomon and Quiel 2006). In hard rock terrain, the task of groundwater potential mapping becomes relatively more complex task involving complex decision owing to lack of reliable data and the highly variable nature of the geologic environment (Kellgren 2002; Anabazaghan et al. 2011) in hard rocks which has low or absence of primary porosity; the intersection of secondary structural features is crucial for productive groundwater (Baramurugan et al. 2010). Groundwater in hard rock aquifers is essentially confined to fractured horizons as the flow of water is mostly through these fractures. Therefore, intensive hydrogeological investigations are precondition to thoroughly appreciate groundwater condition in hard rock region (Baramurugan et al. 2010; Solomon and Quiel 2006; Anbazhagan et al. 2015) to delineate groundwater potential zones through GIS and remote sensing which act as powerful tools, and several studies have been carried out in different parts of the world (Saraf and Chowdhury 1998; Ganapuram et al. 2009; Ndatuwong and Yadev 2014; Pandian and Kumanan 2013; El-Naqa et al. 2009).

There are various statistical methods that were adopted by various authors for groundwater potential mapping elsewhere such as: frequency ratio (Guru et al. 2017; Al-Zuhairy et al. 2017; Razandi et al. 2015), Analytical hierarchical process (Rahmati et al. 2015; Chowdhury et al. 2009; Razandi et al. 2015), binary logistic regression method (Ozdemir 2011a), weight of evidence model (Ghorbani et al. 2017; Tahmassebipoor et al. 2016; Ozdemir 2011b), k-nearest neighbor (Naghibi and Dashtpagerdi 2017), Demster-Shafer model (Rahmati and Melesse 2016), machine learning model/artificial neural network (Lee et al. 2012), boosted regression tree BRT (Naghibi and Pourghasemi 2015; Naghibi et al. 2016), multivariate adaptive regression spline (Zabihi et al. 2016), maximum, entropy model (Rahmati et al. 2016), generalized adaptive model (Falah et al. 2016), random forest model (Rahmati et al. 2018), and other GIS-based models such as earth observation and entropy weighted linear aggregate novel approach (Bandyopadhyay et al. 2007; Al-Abadi et al. 2016). In the above studies, themes such as vegetation, land use/land cover, hydrogeomorphology, drainage, lithology, subsurface lithology, structure, and slope were interpreted to infer groundwater potential.

The present study is focused on delineating groundwater occurrence using GIS-based model of geological and hydrogeological parameters which are conditioning factors for groundwater occurrence. In Oban Massif, which is a hard rock terrain with low success ratio of drilled boreholes leading to water scarcity in the area and combined with the increase in demographic and economic activities, resulting from increased mining and quarrying activities, the demand for potable water has increased exponentially. In the light of the above, delineating sources of groundwater potential is used a means of developing groundwater potential map, which is a valuable guide for groundwater exploration and exploitation. This is because no such automated study has been carried out in the study area, except manual lineament studies from satellite remote sensing imageries and geophysical techniques in the area (Okereke et al. 1996; Edet and Okereke 1997; Edet et al. 1994, 1998).

To achieve the above end, the study has developed objectives such as to generate groundwater potential map to identify suitable sites for siting boreholes, compute the aquifer parameters which are a valuable guide for groundwater occurrence, and juxtapose them with areas delineated as suitable sites for groundwater occurrence. The result of this groundwater occurrence study will be a helpful guide for groundwater developers, which engineers on water resource management and land-use planning to select suitable areas to implement development schemes and also government agencies.

\section{Study area description}

The study area Oban Massif and environs is situated in Akamkpa and Biase Local Government areas in Cross River state Nigeria. The area is located between latitudes $05^{\circ} 18^{\prime} 57.7^{\prime \prime}-05^{\circ} 45^{\prime} 26.8^{\prime \prime}$ and longitudes $08^{\circ} 34^{\prime} 39.4^{\prime \prime}-08^{\circ} 5^{\prime} 20.5^{\prime \prime}$ (Fig. 1). The study is bounded by Cameroon in the east, Ebonyi state in the west, Calabar Flank in the south, and Mamfe Embayment in the Northern part. The area encompasses non-prolific boreholes in the basement complex within the Oban Massif and the prolific aquiferous sedimentary terrain in the adjoining Mamfe Embayment. Temperature range of $28-36{ }^{\circ} \mathrm{C}$ and annual rainfall of about $2000 \mathrm{~mm}$ characterize the study. The area experience wet and dry seasons. The peak of rainfall is recorded in the month of June through September and fluctuates annually. Regional runoff coefficient of the study area is 


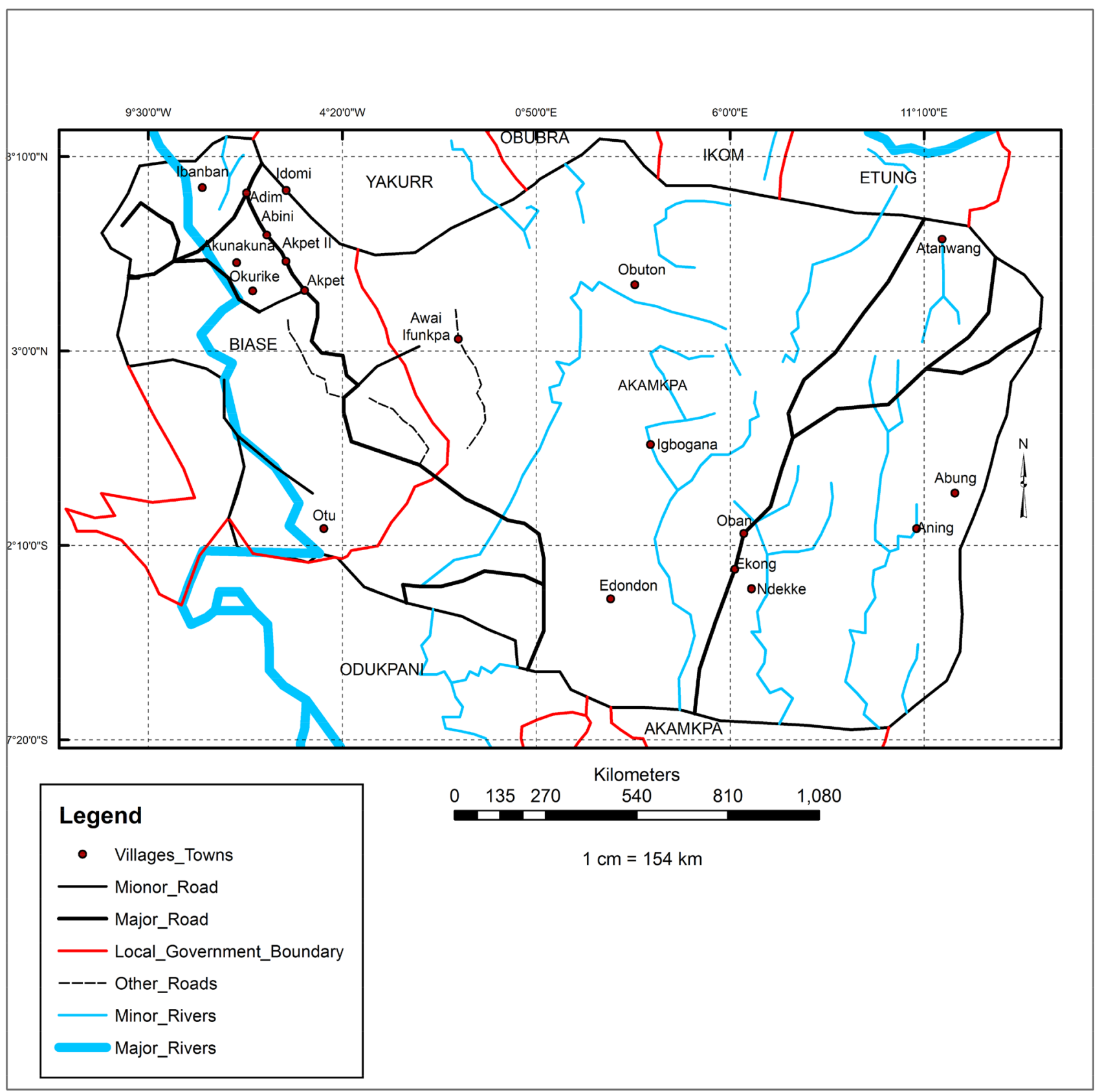

Fig. 1 Location map of the study area

in the order of $0.21-0.61$, which is influenced by topography and evaporation (Cross River Basin Development Authority [CRBDA] 2008).

\section{Geology and hydrogeology}

Ekwueme (2003) described rocks in Oban Massif as Pan African. Common rocks identified by the author in the western Oban Massif include: biotite-garnet hornblende gneiss, kyanite gneiss and biotite hornblende gneiss. Other rock types in Oban Massif are amphibolites, schists, phyllites, and granodiorite which are dominant in the western Oban Massif. Charnokites occur in the gneisses in eastern Oban Massif and granodiorite in the west. The charnokites are coarse grained but not foliated (Nganje 1995). Metamorphic isograd and zones are in politic schist and gneisses of Uwet area in Oban Massif (Ekwueme 1993).

There is an outcrop of schist near Aningeje and Abiati up to Kwafalls area (Fig. 2). The schist at Kwafalls is 
banded and associated with pegmatite. Banded gneisses of early Proterozoic age are found in Oban town (Fig. 2). The sediment basement contact as exposed at Awi Formation lies unconformably on migmatite gneiss complex. From field evidence, the most conspicuous intrusive rocks in western Oban Massif in particular are granodiorite. The schist is dominant in western Oban Massif and is in the green schist facies (Ekwueme 1995). In the environs of the study area, Eze Aku Group shows sand stone ridges at Abini and Adim. Basal and more marine parts of the ridges are in Idomi and Agwagwune (Fig. 2).

The hydrogeological setting is such that ground water may be present in either weathered overburden or along fracture faults systems. In the study, the resistivity of the water saturated aquifer bearing formation ranges from 280 to $740 \mathrm{Ohm}$ with thickness of 5-140 m with limited hydraulic conductivity of $8.53-13.18 \mathrm{~m} /$ day and transmissivity ranges from 410.65 to $725.88 \mathrm{~m}^{2} /$ day (Edet and Okereke 1997). Okereke et al. (1996) established the top layer of less than $5 \mathrm{~m}$ thick. The aquiferous unit has thickness varying between 1.5 and 70 m not exceeding $30-40 \mathrm{~m}$. Depth to water table is estimated at $3 \mathrm{~m}$ of the observed depth. The groundwater is unconfined and the aquifer is recharged directly by direct precipitation from rainfall (Okereke et al. 1996).

In Oban Massif, a drilled well at Awi, the overburden thickness measured $60 \mathrm{~m}$. At a drilled depth of $24 \mathrm{~m}$ into the overburden production well recorded an estimated yield of $1.9 \mathrm{l} / \mathrm{s}$. This depth with a saturated thickness of $19 \mathrm{~m}$ was considered adequate for exploitation using a hand-pump-equipped borehole. Some hydraulic parameters such as depth to bedrock, static water level, and overburden thickness at Uyanga, Awi, and Mbarakom are found in Edet et al. (1994). Oban Massif generally has low aquifer parameters in most locations, which is a strong indication of poor water storage potential in the basement complex. Joints and cracks may appear in the bed rock, yet its water retention capacity is poor. Ground water storage in the study can be facilitated by regolith thickness (George and Okwueze 2002).

\section{Geologic structures}

Oden, et al. (2012) identified four fracture sets in Oban Massif, namely: NNSW-SSE trending $150^{\circ}-160^{\circ}$ from N, NNE-SSW $20^{\circ}-40^{\circ}$ from N, E-W $70^{\circ}-90^{\circ}$, and NW-SE $120^{\circ}-130^{\circ}$. The Nigerian basement complex has been subjected to several generations of folding, faulting, shearing, and fracturing (Ekwueme 2003). Recognizable linear features in basement complexes are folds, axes, mineral lineations, boudins, and pinch and swell. Edet et al. (1994) and Edet and Okereke (1997) confirmed lineament trends in NS to NE-SW in Oban Massif, but Okonny (1984) did not recognized $\mathrm{N}-\mathrm{S}$ trending of lineaments in Oban Massif using radar imagery.

Ekwueme (2003) identified four maxima from stereogram plot of lineaments, with dominant trend in all cases in $\mathrm{N}-\mathrm{S}$ to NE-SW (0-500) and NW-SE $\left(10^{\circ}-140^{\circ}\right)$ direction. Oden (2012a) established structural features in NNW-SSE as the dominant preferred orientation. Average lengths of pegmatitic veins are estimated at $20 \mathrm{~m}$ and most frequently $2-3 \mathrm{~m}$ (Oden 2012b).

\section{Materials and methods}

Topographical, geological, hydrogeological, and structural maps on a scale of 1:250,000 were obtained from Nigerian Geological Survey Agency and Cross River Basin Development Authority (CRBDA 2008). Fieldwork was carried out in the study area and field data on strike and dip values and foliation trend of rock exposures in the study was acquired. Lithologs on borehole-drilled samples and borehole completion reports and pumping test results from the study area were obtained from Cross River State Rural Water Supply and Sanitation Agency and Cross River Basin Development Authority.

The structural map of the study was digitized from hydrogeological and structural map of the study area. The geologic map was produced by superimposing field geologic data on the topographical map and digitized to produce the geologic map. Multicriteria evaluation was used to prepare the thematic geologic groundwater prospect map of the study. Relative weights were assigned to the various rock types based on their relative contribution to groundwater occurrence and the thematic map was reclassified using geographic information system software (ArcGIS 10.1). From the reclassified map, a geologic ground water prospect map was produced using spatial analyst tool in ArcGIS software, showing the various favourable ground water prospect zones based on the geology of the area. Data on lithologs were processed using a geological software known as rockworks to construct a lithology correlation section. Hydrogeological parameters were computed using available pumping test and well completion data. Finally, values of aquifer parameters across the study were analyzed using Excel Microsoft software application to construct a histogram showing the distribution of aquifer parameters in localities across the study area. Surfer8 software was used to prepare rose diagram from measured structural information from the field showing fracture orientation.

\section{Results and discussion}

Image data on geological structure and hydrogeological parameters analyzed in this study are presented as follows. 


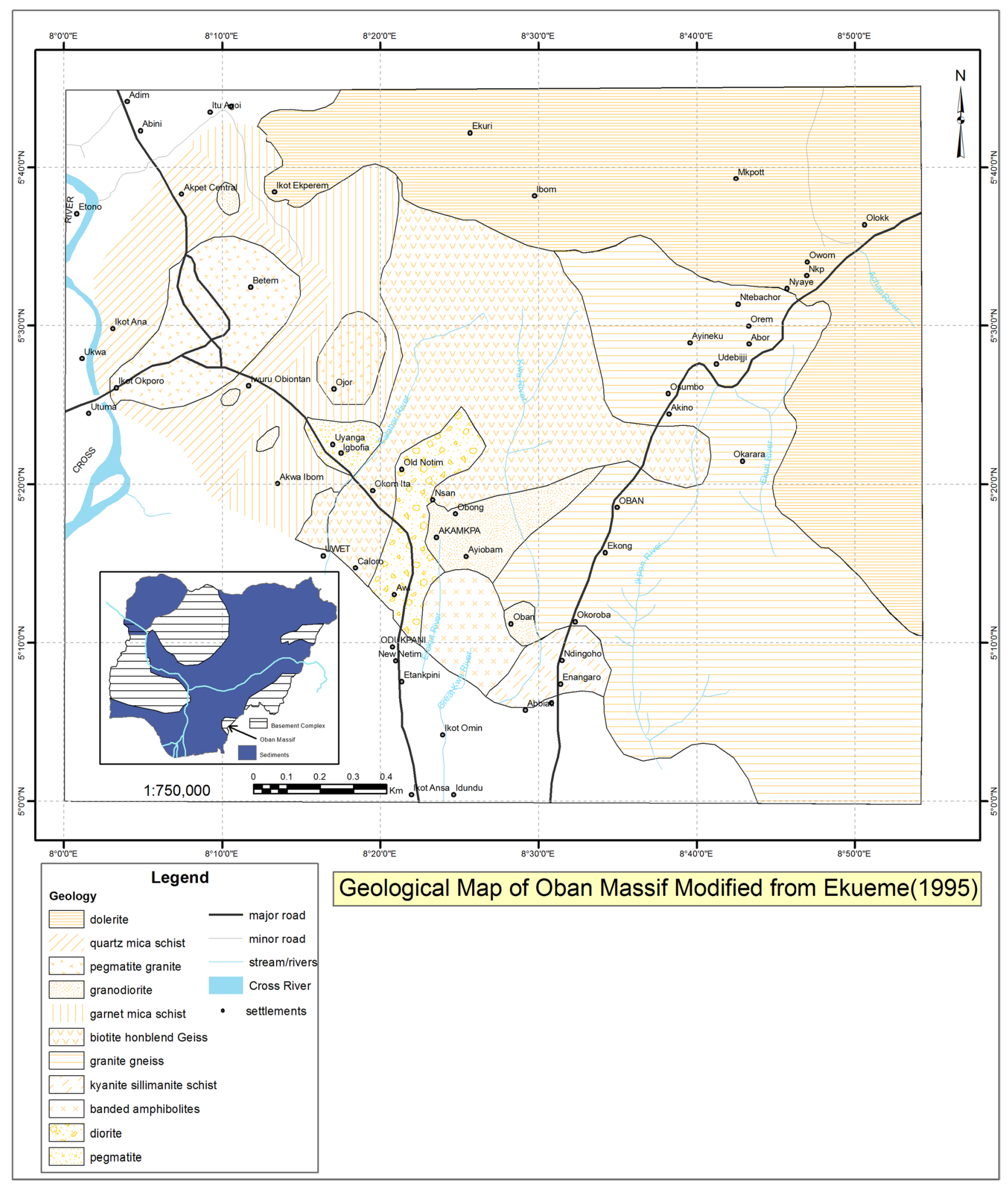

Fig. 2 Geological map of the study area 


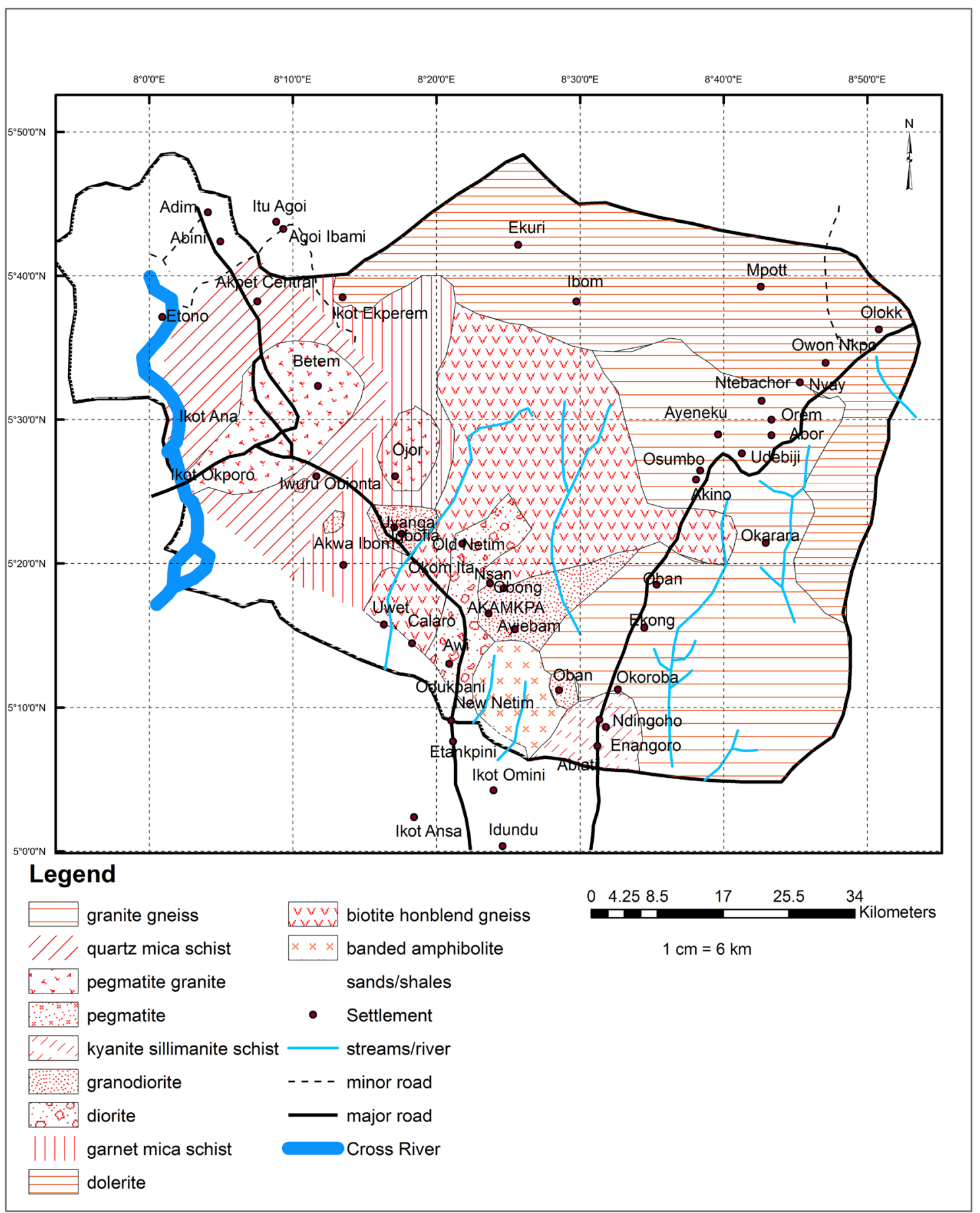

Fig. 3 Modeled geological map of the study area

\section{Geology}

The geology of Oban Massif (Fig. 2) shows that the eastern flank of the Massif is mostly weathered granites, banded amphibolite, and pegmatitic gneisses, and western flank is mostly granodiorite and schistose rocks. The various rock types were given a weighting factor based on their suitability for groundwater occurrence. The various rock types in Fig. 3 show the geologic map circumscribed by boundaries of the study area. The reclassified geologic map in Fig. 4 shows sandstones, silts, and gravelly aquifers are classified as very good for ground water storage, while weathered pegmatites 


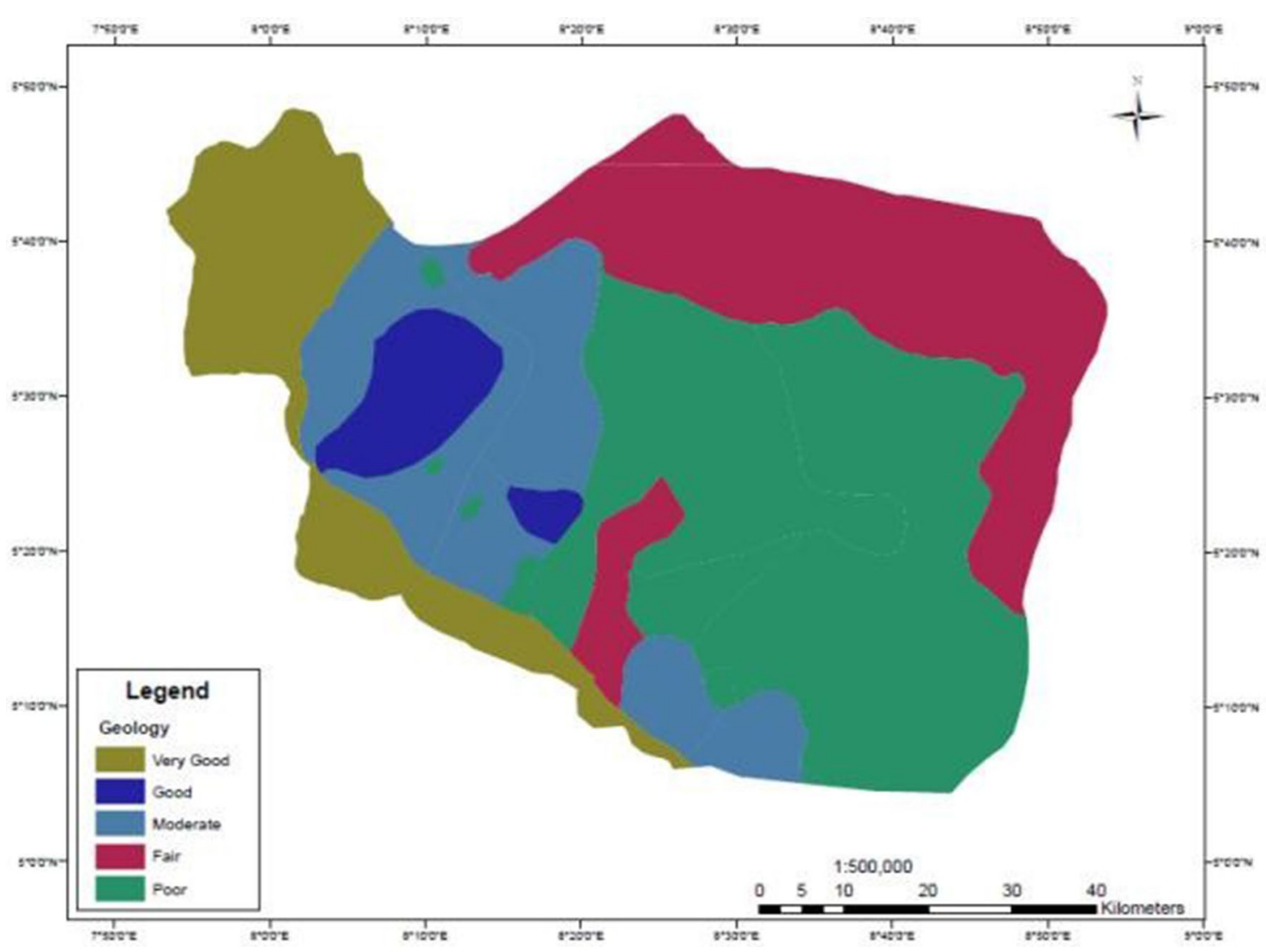

Fig. 4 Geological groundwater prospect map of the study area

were ascribed to be of good aquiferous units. Banded amphibolites and schist are moderately good aquifers. Dolerites and diorites were assigned to be fair in groundwater occurrence, but unfractured granite gneiss and granodiorite were noted to be poor aquifers unless when imparted with secondary porosity.

The aquifers in the study are made of weathered basement rocks with basement detrital overburden aquifer and fractured aquifer rock (Okereke et al. 1996). Granitic rocks offer lowest yield boreholes owing to the impervious nature of the rock, while pegmatites are commonly a locus of tectonic movement and can be prolific aquifers for groundwater (Hazella et al. 1992). The sedimentary region is mainly sandstones, silts, gravelly sands, clays, and shale which are porous enough to be producible aquifers. Igneous and metamorphic rocks are not recognized as big water producers without secondary porosity and permeability being imparted by faulting and fracturing (Weight 2004; Huntoon and Lundy 1980). On the contrary, sedimentary rocks are the most common water bearing materials for potable water (Weight 2004; Cherry and Freeze 1979). These views are in agreement with this work, because sedimentary rocks were reported on reclassified geologic map as very good for groundwater prospect. The hard rock region was modeled as being good, fair to poor for groundwater prospect based on degree of fracturing. The lithology of the exposed rock is vital in controlling groundwater. Studies by Edet et al. (1994, 1998), Edet (1996), and Mogaji et al. (2011) stressed on lineament and drainage factors in groundwater occurrence. This may be explained by the fact that lineament and drainage are indicators of primary and secondary porosity and so provide lithology information (El-Naqa et al. (2009), but this is not sufficient justification. This is the gap bridged in this study by elaborating on Geology as a ground water controlling factor.

Sereme (2003) modeled groundwater occurrence and assigned the highest weight of 80 to alluvium and basalt which he considered having more favourable properties for ground water occurrence due to their primary porosities and permeability. Granitoids and schistose rocks due to the joints and secondary structures from foliation are also adjudged to be of better ground water accumulation in the said study. In the same vein, in this modeling, sandstones, schist, and foliated amphibolite were considered to be favourable for ground water occurrence and were given a higher weighting factor among the hard rocks in the study area. The cause of borehole failure is mostly due to the geologic formation. That is why groundwater prospect assessment is incomplete 
without considering the geology as one of the groundwater controlling factors.

The rose diagram (Fig. 4) constructed from the structural data gathered from the study area shows the fracture orientation to be of N-S, SSW-SSE, NE-SW, and NW-SE, which is in agreement with the findings of Oden et al. (2012), Ekwueme (2003), Edet et al. (1994) and Edet and Okereke (1996) that there is lineament trending $\mathrm{N}-\mathrm{S}$ as opposed to the view of Okonny (1984) that there are no fracture sets trending $\mathrm{N}-\mathrm{S}$ in the study area.

\section{Lithologic characteristics and hydrogeological parameters}

Lithologs of boreholes drilled across the study area (Fig. 5) show depth of aquifers in the Oban Massif ranging from 17 to $29 \mathrm{~m}$, both in basement and sedimentary area which was sampled as controlled. Results show that the overburden thickness is thicker in the western Oban Massif than in the eastern Oban Massif. From the litholog correlation section (Fig. 5), the weathered basement is about $21 \mathrm{~m}$ thick at Aningheje, while the overburden thickness is $19 \mathrm{~m}$. An overburden thickness of $6 \mathrm{~m}$ was measured at Abiati. Ayaebam has $14 \mathrm{~m}$ overburden thickness. A thickness of $17 \mathrm{~m}$ was recorded at Obung. At Akamkpa Urban, the overburden thickness is $19 \mathrm{~m}$. The aquifer depths were $14,16,15,31$, 33, and $23 \mathrm{~m}$ at Oban, Aningheje, Nsan, Nsun Nkana, and Obung, respectively. A database of hydrogeological parameters collected from borehole aquifer test performed across the study area is presented in Table 1. Aquifer parameters such as transmissivity, specific capacity, storativity, drawdown, pumping rate, static water level (SWL), and total depth of strata penetrated were computed in boreholes situated at Anigheje, Abiati, Abini, Etono, Ikot Okpora, Agwagwune, Akpet Central, and Adim. Others are Idomi, Nsun Nkana, Akamkpa Urban, and Big Iwuru (Fig. 6).

Boreholes were shallower in the basement than in sedimentary region (Fig. 5) and the yields were correspondingly higher in the sedimentary region than the basement terrain. There is no significant difference between drilled depths and specific capacity or yield, drilling generally stops once the required depth for the well construction, and the required yield is attained (Hazella et al. 1992). Boreholes drilled through thick overburden greater than $25 \mathrm{~m}$ yields some appreciable quantity of groundwater and regolith aquifer overlying the Precambrian basement rocks are the main source of groundwater in the basement (Anyeakun and Dapaah-Siakwan 2006). The higher borehole yields
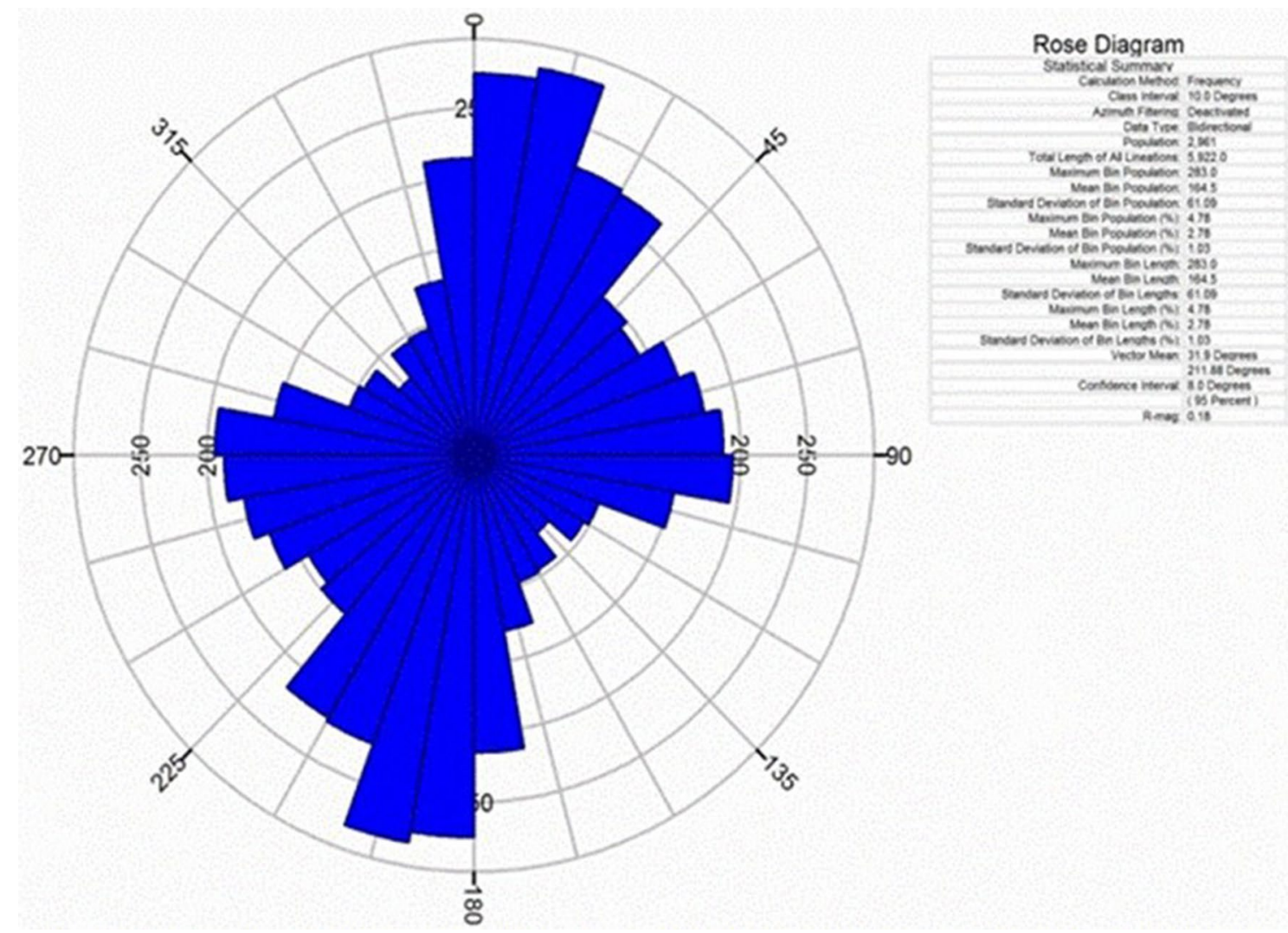

Fig. 5 Rose diagram showing fracture orientation of the study area 
Table 1 Hydrogeological parameters

\begin{tabular}{llllllll}
\hline Locality & $\begin{array}{l}\text { Specific capacity } \\
\left(\mathrm{m}^{3} / \text { day/m) }\right.\end{array}$ & $\begin{array}{l}\text { Transmissivity } \\
\left(\mathrm{m}^{2} / \text { day }\right)\end{array}$ & Storativity & Drawdown $(\mathrm{m})$ & $\begin{array}{l}\text { Pumping } \\
\text { rate }(\mathrm{l} / \mathrm{s})\end{array}$ & SWL (m) & Total depth $(\mathrm{m})$ \\
\hline Aningeje & 16.6 & 12 & $1.2 \times 10^{-3}$ & 2.20 & 0.88 & 6 & 51 \\
Abini & 7.8 & 1.43 & $9.4 \times 10^{-4}$ & 11.98 & 1.08 & 8.4 & 45 \\
Etono & 31.16 & 1.03 & 2.3 & 12.83 & 0.83 & 3.1 & 30 \\
Abiati & 19.8 & 0.126 & 0.28 & 3.20 & 2.2 & 5.80 & 3.2 \\
Ikot okpora & 9.4 & 1.72 & 0.01 & 6.9 & 0.75 & 7.5 & 42 \\
Agwagwune & 9.4 & 1.72 & 0.01 & 6.9 & 0.75 & 3.3 & 42 \\
Akpet Central & 1.81 & 0.0033 & $7.4 \times 10^{-3}$ & 10.10 & 1.83 & 10.50 & 30.3 \\
Adim & 1.92 & 0.0614 & 0.1386 & 24.40 & 0.78 & 2.9 & 31.3 \\
Akamkpa Urban & 2.88 & 0.527 & 1.186 & 3.46 & 3.57 & 10 & 55.4 \\
Nsun Nkana & 2.88 & 0.527 & 1.186 & 4.46 & 3.57 & 20 & 61 \\
Big Iwuru & 2.88 & 0.527 & 1.186 & 4.46 & 3.57 & 20.5 & 61 \\
Idomi & 15.01 & 1.5 & $3.5 \times 10^{-1}$ & 17.65 & 2.893 & 9.2 & 53 \\
\hline
\end{tabular}

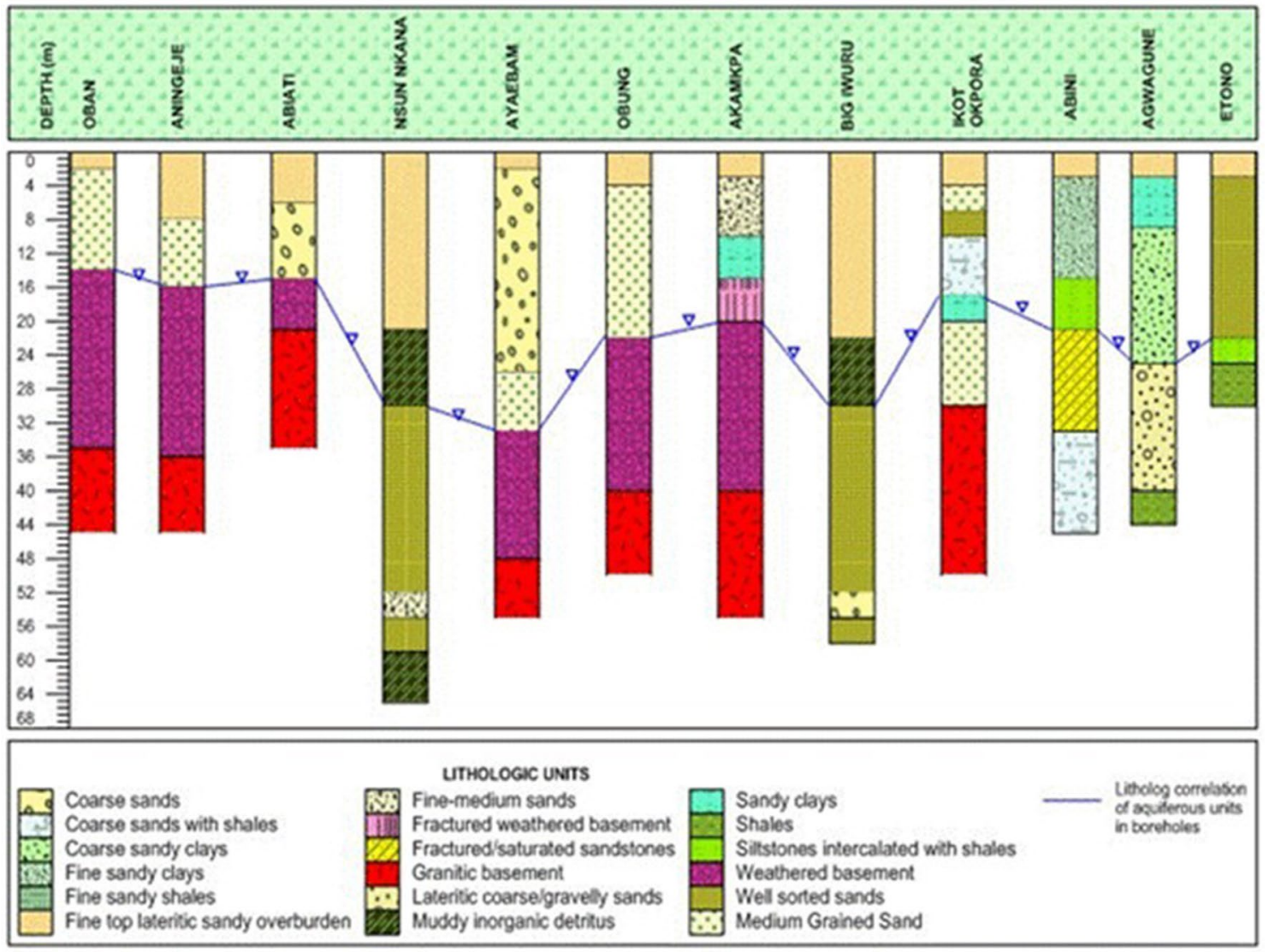

Fig. 6 Lithological correlation cross section of the study area

localities which are found to be situated in the area classified as very good groundwater prospect zones in the reclassified geologic map (Fig. 4).

Among the localities, the specific capacity ranged from 1.88 to $19.8 \mathrm{~m}^{3} / \mathrm{day} / \mathrm{m}$. The least value was obtained at
Akpet Central and the highest value at Aningheje. Storativity values ranged from 0.0033 to $12 \mathrm{~m}^{3} /$ day. The least value was recorded at Akpet Central and the highest value at Aningeje. Storativity values has the least and highest values of 0.007 and 2.3 , respectively. The highest value was indicated at 
Etono and the least value recorded at Akpet Central. The drawdown values ranged from 3.20 to $24 \mathrm{~m}$. The least drawdown was obtained at Abiati and the highest drawdown at Adim. The static water level ranged from 2.9 to $20.5 \mathrm{~m}$. The least value was noted at Adim and the highest value at Big Iwuru. Pumping rate values ranged from 0.75 to $3.57 \mathrm{l} / \mathrm{s}$. The least value occurred at Ikot Okpora and Agwagwune and the highest value at Nsun Nkana and the least depth at Etono.

Borehole yields and specific capacities are noted to be low in regolith aquifers (Umah and Kehinde 1994). This may explain why the yields are low in basement aquifers. A weathered and decomposed fractured basement overlain by relatively deep zone of well-decomposed rock and regolith/ hard rock interface is suitable for groundwater occurrence in basement (Umah and Kehinde 1994; Anyeakun and DapaahSiakwan 2006). This may be responsible for high borehole yield at Abiati (Fig. 6 and Table 1). The deep-weathered localized areas have a better hydrogeologic prospect in basement complex terrains (Faniran and Omorinbola 1980; Agbede 1996; Ajayi and Hassan 1990; Greenbaum 1992; Carruthers et al. 1991). In addition, optimum borehole yields are achieved when the borehole penetrates both the lower saprolite and the overlying fractured basement (Davies and Robins 2007). This may be the reason for good borehole yields in some parts of the basement of the study area. Some sandstone aquifer demonstrate moderate yield that this may be due to the fact that the younger tertiary sandstone usually retain some degree of primary porosity between the grains and also due to the intercalations with shale and clays and are typical of moderate permeability (Chilton and Seiler 2006).

Although Sereme (2003) opined that borehole yield is not an accurate parameter to assess borehole performance on account that well yield is born out of pump efficiency, it is still a determinant factor for borehole performance. The high well yield at Nsun Nkana and Big Iwuru (Fig. 6 and Table 1) is due to sandstones/gravelly aquifers, while the high yield at Akamkpa urban could be explained by thick weathered overburden aquifers. Weathered basement aquifers generally provide only modest yields from individual production boreholes. Higher yields to support motorized pumping and water reticulation can be obtained at locations where favourable geology, structural features, and weathering are combined (Chilton and Forster 1993).

Specific capacity of rock types exercise control over aquifer characteristics of these weathered products (Hazella et al. 1992). Specific capacity of a borehole can be used to classify boreholes in Aningheje, Etono, Abiati, and Adim to be of good performance and those in Abini, Ikot Okpora, Agwagwune, Idomi, Nsuk Nkana, Akamkpa, and Iwuru to be of moderate performance using the classification scheme adopted by Ishaku et al. (2009) in basement and sedimentary areas at Taraba state Nigeria (Fig. 7). Specific capacity of

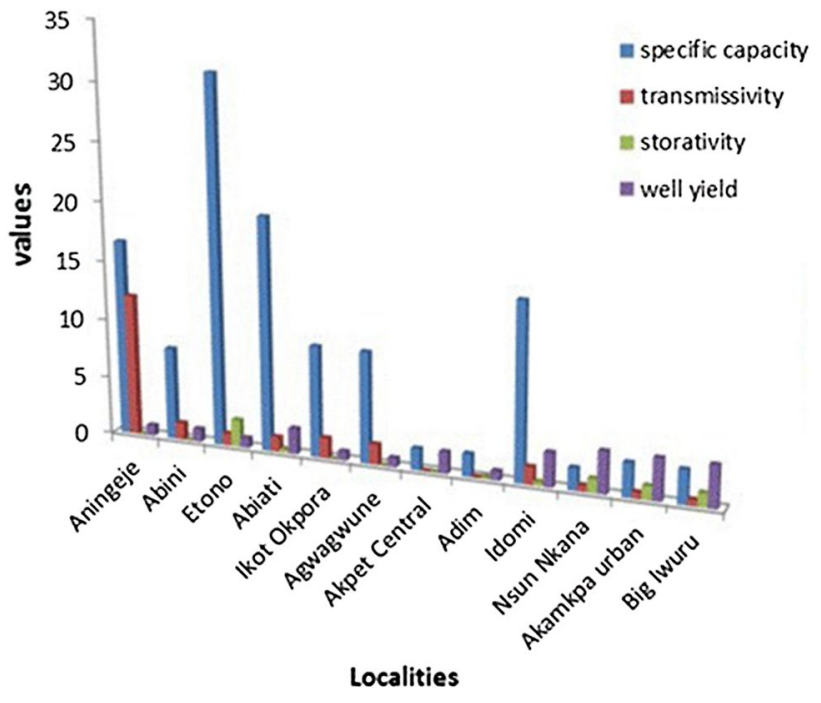

Fig. 7 Distribution of aquifer parameters in the study area

an aquifer rock matrix generally gives better indicator of aquifer performance than borehole yield, since it also reflects aquifer transmissivity and thickness (Umah and Kehinde 1994). Using transmissivity as a determinant factor of borehole performance, all the boreholes in Table 1 are below high potential aquifers, because Offodile (2002) advocated a transmissivity value between 5 and $50 \mathrm{~m}^{2} /$ day to achieve high potential of groundwater in a basement crystalline rock environment.

\section{Conclusion}

The Oban Massif is the Precambrian basement complex with a top lateritic overburden underlain with weathered granitic rocks which constitute the unconfined aquiferous unit. Geological formation is an influential factor in controlling groundwater occurrence. Groundwater prospect in the study has more considerable prospect in the sedimentary terrain than in the basement complex rocks. Weathering and fracturing impart secondary porosity on basement rocks which sustain groundwater potential in hard rock terrain. The direction of groundwater flow is from the eastern flank of the Oban Massif to the western flank enroute the sedimentary aquifers in the adjoining Mamfe Embayment region. Borehole depths in the basement are shallower than those drilled in the sedimentary area. Aquifer parameters obtained from aquifer test in boreholes across the study area such as specific capacity $\left(1.81-31.16 \mathrm{~m}^{2} /\right.$ day $/ \mathrm{m})$, transmissivity $\left(0.0033-12 \mathrm{~m}^{2} /\right.$ day $)$, storativity $(9.4 \times 10-2.3)$, drawdown $(2.2-17.65 \mathrm{~m})$, pumping rate $(0.75-3.57 \mathrm{l} / \mathrm{s})$, static water level $(0-20.5 \mathrm{~m})$, and total depth $(3.2-61 \mathrm{~m})$ indicate better correspondence with 
zones identified from model geologic map for groundwater prospective zones. Five classes of groundwater prospective zones such as very good, good, moderate, fair, and poor zones were identified in the geologic groundwater prospect map. Part of the study categorized as very good covered an area of about $28.73 \mathrm{~m}^{2}$. Good water prospect zone occupied an area of about $9.66 \mathrm{~m}^{2}$, while the moderate water potential is about $35.08 \mathrm{~m}^{2}$. The fair and poor water zones had area coverage of about 49.38 and $77.63 \mathrm{~m}^{2}$, respectively. Poor water potential zone occupied the largest part of the study, while the very good water potential area occupied the least area.

The type of geologic formation is paramount in determining aquifer performance. Well yield is not a very reliable aquifer performance indicator, because it depends largely on the efficiency of the pump installed. Other aquifer parameters such as transmissivity, specific capacity, and storativity must be employed in aquifer performance assessment. Due to scale and colour shading, the categorized groundwater zones appear as if basement aquifers are not discontinuous, whereas, in reality, they are discontinuous. Therefore, it should be noted that the areas shaded as very good, good, moderate, and fair and poor have intervening regions that are not in the designated class, but cannot be discerned by the human eye. Geographic information system modeling of geologic structural data at regional extent is rapid and cost-effective method. It provides a means of effective planning and quick decision making on the exploration, exploitation, and management of groundwater in a particular geologic terrain.

Acknowledgements I wish to appreciate Mr Ubom Okon of Department of Geoinformatics University of Uyo for assisting at various stages of data analysis. I am thankful to my Children: Uyimkanu, Sikakwe Jnr., Uyunkwe, Apifeh, Akangbe, and Uyeyouglechiemin for bearing with me all through the period of research and permitting me to divert the finances meant for their upkeep to fund this research. God bless all of them.

Author contributions Dr. GS is a lecturer of Environmental Geosciences in Federal University Ndufu-Alike Ikwo. He obtained a Ph.D. in Environmental Geosciences and Pollution Studies from the University of Calabar, since 2014. His research concentration is in environmental geochemistry and geospatial analysis.

Open Access This article is distributed under the terms of the Creative Commons Attribution 4.0 International License (http://creativeco mmons.org/licenses/by/4.0/), which permits unrestricted use, distribution, and reproduction in any medium, provided you give appropriate credit to the original author(s) and the source, provide a link to the Creative Commons license, and indicate if changes were made.

\section{References}

Agbede OA (1996) Groundwater modeling. An overview. J Min Geol 32(2):105-107
Ajayi CO, Hassan M (1990) The delineation of the aquifer overlying the basement complex in the western part of the Kubanni basement in Zaria (Nigeria). J Min Geol 26(1):10-20

Al-Abadi AM, Pourghasemi HR, Shahid S, Ghalib HB (2017) Spatial mapping of groundwater using entropy weighted linear aggregate novel approach and GIS. Arab J Sci Eng 42(3):1185-1199

Al-Zuhairy MSH, Hassan AA, Schnewer FM (2017) GIS based frequency ratio model for mapping the potential zoning of groundwater in the western desert of Iraq. Int J Sci Eng Res 8(7):52-65

Anabazaghan S, Balamuragan G, Biswal TK (2011) Remote sensing in delineating deep fracture aquifer zones. In Anbazaghan S, Subramanian SK, Yang X (eds) Geoinformatics in Applied Geomorphology. CRC Press, pp 205-229

Anbazhagan S, Indhirajith R, Uma Maheshwaran S, Jothibasu A, Venkatesan A, Ramesh V (2015) Electrical resistivity survey and shallow subsurface geological study in hard rock terrain. Southern India. J Geol Soc India 85(3):305-312

Anyeakun WA, Dapaah-Siakwan S (2006) The occurrence of groundwater in northern Ghana. Appl Groundw Stud Afr 3:205-207

Bala AE (2009) Field evidence of occurrence of groundwater in Gombe Formation around Barambu and Gedawo northern Nigeria. Afr J Environ Sci Technol 3:198-205

Berhanu B, Seleshi Y, Melesse A (2014) Surface water and groundwater resources of Ethiopia: potentials and challenges of water resources development. In: Melesse A, Abtew W, Setegn S (eds) Nile River Basin. Springer, Netherlands, pp 97-117

Bandyopadhyay S, Srivastava SK, Jha MK, Hegde VS, Jayaraman V (2007) Harnessing earth observation (EO) capabilities in hydrogeology: an Indian perspective. Hydrogeol J 15(1):155-158

Baramurugan G, Bhattacharya D, Singh HN, Shaker D (2010) Evaluation of hydrogeology of the lower Son Valley based on remote sensing data. J Geogr Inf Syst 2:220-233

Carruthers RM, Greenbaum D, Pert RJ, Herbert R (1991) Geophysical investigation of photo lineaments in southwest Zimbabwe. Q J Eng Geol 24:437-451

Cherry J, Freeze A (1979) Groundwater. Prentice Hall, New Jersey

Chilton PJ, Forster SD (1993) Characterization and water supply potential of basement aquifers in tropical Africa. Hydrogeol J 3(1):36-47

Chilton J, Seiler KD (2006) Protecting groundwater for health. In: Howard SG, Chilton J, Chres I (eds) Managing the quality of drinking water sources. IWA publishers, London, pp 20-24

Chowdhury A, Jha MK, Chowdhury VM, Mal BC (2009) Integrated remote sensing and GIS based approach for accesing groundwater potential in west Medinipur district West Bengal. India. Int $\mathbf{J}$ Remote Sens 30(1):231-250

Cross River Basin Development Authority (2008) Detailed data collection, collation and ground truthing campaign of 500 boreholes in hydrogeological area for the enrichment of hydrological information for the hydrological mapping of Nigeria. Draft final report. Nigeria Cross Rive State Ministry of Water Resources, pp 9-15

Davies J, Robins NS (2007) Groundwater occurrence north of Limpopo. Are erosion surface the key? British Geological Survey, Oxford, pp 10-20

Edet AE (1996) Evaluation of borehole sites based on air photo derived parameters. Bull Int Assoc Eng Geol 54:71-74

Edet AE, Okereke CS (1997) Assessment of hydrogeological conditions in basement aquifers of the Precambrian Oban massif, southeastern Nigeria. J Appl Geophys 36:195-204

Edet AE, Teme SC, Okereke CS, Esu EO (1994) Lineament analysis for groundwater exploration in Precambrian Oban Massif southeastern Nigeria. J Min Geol 30(1):32-65

Edet AE, Okereke CS, Teme SC, Esu EO (1998) Application of remote sensing to groundwater exploration. A case study of the Cross River State southeastern Nigeria. Hydrogeol J 6(3):394-404

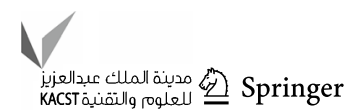


Ekwueme BN (1993) An easy approach to metamorphic petrology. University of Calabar press, Calabar

Ekwueme BN (1995) The Precambrian Geology of Oban Massif southeastern Nigeria. Geological excursion guide book to the Oban Massif, Mamfe Embayment and Calabar flank. Southeastern Nigeria. In: 31st annual conference of the Nigerian Mining and geosciences Society Calabar, March 12-16

Ekwueme BN (2003) The Precambrian Geology and evolution of the southeastern Nigeria basement complex, vol 39. Calabar University Press, Calabar, p 60

El-Naqa A, Hammouri N, Ibrahim K, El-Taj M (2009) Integrated approach for groundwater exploration in Wadi Arab using remote sensing and geographic information system. Jordan J Civ Eng 3(3):223-235

Falah F, Ghorbani NS, Rahmati O, Daneshfar M, Zeinivard H (2016) Application of generalized additive model in groundwater modeling and comparison of its performance by bivariate statistical methods. Geocarto Int (accepted)

Faniran A, Omorinbola M (1980) Evaluating the shallow groundwater resources in basement complex areas. A case study of southeastern Nigeria. J Min Geol 17(1):65-70

Ganapuram S, Vijaya Kumar GT, Murali Krishna IV, Kahya E, Cüneyd Demirel M (2009) Mapping of groundwater potential zones in the Musi basin using remote sensing data and GIS. Adv Eng Softw 40(7):506-518

George AM, Okwueze EE (2002) Seismic refraction investigation of groundwater potential in parts of Oban Massif, southeastern Nigeria. Glob J Geol Sci 1(1):43-47

Ghorbani NS, Falah F, Daneshfar M, Haghizadeh A, Rahmati O (2017) Delineation of groundwater potential zones using remote sensing and GIS based data driven models. Geocrto Int 32(2):167-187

Greenbaum D (1992) Structural influences on the occurrence of ground water in southern Zinbabwe. Br Geol Soc Special Publ 66:77-85

Guru B, Seshan K, Bera S (2017) Frequency ratio model for groundwater potential mapping and its sustainable management in cold desert. India. J King Saud Univ Sci 29(3):333-347

Hazella JRT, Cratchley CR, Jones CRC (1992) Hydrogeology of crystalline aquifers in northern Nigeria and geophysical techniques used in their exploration. Geol Soc Lond Special Publ 66:164-166

Huntoon PW, Lundy DA (1980) Fracture controlled groundwater circulation and well siting in the vicinity of Laramie Wyoming. Groundwater 17(5):25-78

Ishaku JM, Kwade AA, Adekeye JIB (2009) Hydrogeological characterization and water supply potential of basement aquifers in Taraba northeastern Nigeria. Nat Sci 7(3):1545-1740

Jha MK, Chowdhury A, Chowdary VM, Peiffer S (2007) Groundwater management and development by integrated remote sensing and geographic information systems: prospects and constraints. Water Resour Manag 21(2):427-467

Kellgren N (2002) Applicability of remote sensing techniques to groundwater exploration in a semi-arid hard rock terrain. A systematic approach. Chalmers publication Library-Chalmers University of Technology

Lee S, Song KY, Kim Y, Park I (2012) Regional groundwater productivity potential mapping using geographic information system neural network model. Hydrogeol J 20(8):1511-1527

Mogaji KA, Aboyeyi OS, Omusuyi S (2011) Mapping of lineaments for groundwater targeting in the basement complex region of Ondo State Nigeria using remote sensing and geographic information system techniques. Int J Water Resour Environ Eng 3(7):150-160

Naghibi SA, Dashtpagerdi MM (2017) Evaluation of four supervised learning methods for groundwater spring potential mapping in Khalkhal region (Iran) using GIS-based features. Hydrogeol J 25(1):169-189

Naghibi SA, Pourghasemi HR (2015) A comparative assessment between the three machine learning models and their performance comparison by bivariate and multivariate statistical methods in groundwater potential mapping. Water Resour Manag. https://doi. org/10.1007/s11269-105-1114-8

Naghibi SA, Pourghasemi HR, Dixon B (2016) GIS-based groundwater potential mapping using boosted regression tree, classification and regression tree, and random forest machine learning models in Iran. Environ Monit Assess 188:44

Ndatuwong LG, Yadev GS (2014) Integration of hydrogeological factors for identification of groundwater potential zones using remote sensing and GIS techniques. J Geosci Geomat 2(2):2-7

Nganje TN (1995) Petrology, geochemistry and age of Uwet granodiorite southeastern Nigeria. MSc thesis, University of Calabar, Nigeria, Department of Geology. Available from University of Calabar Post graduate school library

Oden MI (2012a) The pegmatitic veins of western Oban Massif. Tectonic and lithological controls on physical properties of rocks. J Environ Earth Sci 4:381-389

Oden MI (2012b) Strain partitioning and dimensional preferred orientation in syntectonic granitoid, southeastern Nigeria. Sci World J 7(1):9-13

Oden MI, Okpukpani TA, Amah EA (2012) Comparative analysis of fracture lineaments in Oban massif and Obudu areas, southeastern Nigeria. J Geogr Geol 4(1):36-44

Offodile ME (2002) Groundwater study and development in the Nigeria, 2nd edn. Mecon Geology and Engineering services, Jos

Okereke CS, Esu EO, Edet AE (1996) Determination of potential groundwater sites using geological and geophysical techniques in Cross River State south eastern Nigeria. J Frican Earth Sci 27(1):149-163

Okonny IP (1984) Tectonic analysis of Oban Massif area using radar imagery. Niger J Min Geol 37(1):15-22

Ozdemir A (2011a) Using a binary logistic regression method and GIS for evaluating and mapping the groundwater spring potential in the Sultan Mountains (Aksehir, Turkey). J Hydrol 405(1-2):123-136

Ozdemir A (2011b) GIS-based groundwater spring potential mapping in the Sultan Mountains (Konya, Turkey) using frequency ratio, weights of evidence and logistic regression methods and their comparison. J Hydrol 411(3-4):290-308

Pandian M, Kumanan CJ (2013) Geomatics approach to demarcate groundwater potential zones using remote sensing and GIS techniques in parts of Trichy and Karur district Tamilnadu India. Arch Appl Sci Res 5(2):234-240

Rahmati O, Melesse AM (2016) Application of Dempster Shafer theory, spatial analysis and remote sensing and groundwater potentiality and nitrate pollution analysis in the semi-arid Khuzestan Iran. Sci Total Environ 568:1110-1123

Rahmati O, Samani AN, Mahdavi M, Pourghasemi HR, Zeinivand H (2015) Groundwater potential mapping at Kurdistan region of Iran using analytic hierarchy process and GIS. Arab J Geosci 8(9):7059-7071

Rahmati O, Pourghasemi HR, Melesse AM (2016) Application of GISbased data driven random forest and maximum entropy models for groundwater potential mapping: A case study at Mehran Region. Iran. CATENA 137:360-372

Rahmati KA, Samadi M, Nobre AD, Melesse AM (2018) Development of an automated GIS tool for reproducing the HAND terrain model. Environ Model Softw 102:1-12

Razandi Y, Pourghasemi HR, Neisani NS, Rahmati O (2015) Application of analytical hierarchy process, frequency ratio, and certainty factor models for groundwater potential mapping using GIS. Earth Sci Inform 8(4):867-883

Saraf AK, Choudhury PR (1998) Integrated remote sensing and GIS for groundwater exploration and identification of artificial recharge sites. Int J Remote Sens 19(10):1825-1841

Sereme S (2003) Remote sensing and geographic information system (GIS). Application for groundwater assessment in Eritria. 
Doctoral Dissertation. Royal institute of Technology Sweden, pp $42-63$

Solomon S, Quiel F (2006) Groundwater study using remote sensing and geographic information systems (GIS) in the central highlands of Eritrea. Hydrogeol J 14(6):1029-1041

Tahmassebipoor N, Rahmati O, Noormohamadi F, Lee S (2016) Spatial analysis of groundwater potential using weights-of-evidence and evidential belief function models and remote sensing. Arab J Geosci 9:79

Umah KO, Kehinde MO (1994) Potentials of regolith aquifers in relation to water supply in rural communities: a case study from parts of northern Nigeria. J Min Geol 30(1):100-106
Weight WD (2004) Manual of applied field hydrogeology. MC Graw Hill, New York, p 413

Zabihi M, Pourghasemi HR, Pourtaghi ZS, Behzadfar M (2016) GISbased multivariate adaptive regression spline and random forest models for groundwater potential mapping in Iran. Environ Earth Sci 75:665

Publisher's Note Springer Nature remains neutral with regard to jurisdictional claims in published maps and institutional affiliations. 